EXTENDED REPORT

\title{
Expression of resistance markers to methotrexate predicts clinical improvement in patients with rheumatoid arthritis
}

\author{
J Wolf, T Stranzl, M Filipits, G Pohl, R Pirker, B Leeb, J S Smolen
}

Ann Rheum Dis 2005;64:564-568. doi: 10.1136/ard.2003.014985

See end of article for authors' affiliations

Correspondence to:

Professor Josef S Smolen, Second Department of Medicine, Lainz Hospital, Wolkersbergenstr 1, A1130 Vienna, Austria; josef.smolen@wienkav.at

Accepted 16 August 2004 Published Online First 2 September 2004

\begin{abstract}
Background: Methotrexate is transported into the cell by the reduced folate carrier (RFC) and out of the cell by members of the multidrug resistance protein family (MRP). Transport proteins may affect the therapeutic efficacy of this drug in patients with rheumatoid arthritis.

Objective: To investigate the potential benefit of the presence of RFC and the absence of functional MRP for the efficacy of methotrexate treatment.

Methods: The study involved 163 patients ( 116 female, 47 male; mean age 59.5 years) on methotrexate (mean weekly dose $12.2 \mathrm{mg}$ ). RFC was determined using reverse transcriptase polymerase chain reaction, and MRP function by flow cytometry, using a calcein acetoxymethylesther/probenecid assay. Clinical response to methotrexate was evaluated by the EULAR response criteria and the ACR $20 \%$ improvement criteria. The clinical data were obtained at the beginning of methotrexate treatment and at the time of blood sampling during ongoing therapy. Patients were divided into four groups according to the presence $(+)$ or absence ( - ) of RFC and functional (f) MRP.

Results: FMRP+/RFC+ and FMRP - /RFC - patients more often had good EULAR response rates $160 \%$, $p=0.014$, and $53 \%, p=0.035$, respectively) in comparison with the FMRP $-/ R F C+$ group (29\%); FMRP + / RFC - patients had a low frequency of good disease activity responses.

Conclusions: Absence of FMRP plus presence of RFC did not prove to be related to beneficial effects of methotrexate, but the lack or the presence of both FMRP and RFC led to a significantly better therapeutic outcome. Determination of these markers may predict responsiveness to methotrexate.
\end{abstract}

A t present, methotrexate is the gold standard for the disease modifying antirheumatic drug (DMARD) treatment of rheumatoid arthritis. ${ }^{1-6}$ Although recent insights into its mode of action suggest that its effects are not primarily concerned with folate metabolism, ${ }^{67}$ folate inhibition may at least partly be involved, as an increase in methotrexate dose seems necessary to maintain clinical efficacy in patients receiving folate supplements. ${ }^{8}$

The antimetabolic efficacy of methotrexate is influenced by molecules concerned with the metabolism of folates. In this respect, various proteins and enzymes are involved in the transportation of methotrexate into and out of the cell and in its intracellular retention. The reduced folate carrier (RFC) induces influx of methotrexate into the cell, ${ }^{9}$ while members of the multidrug resistance protein family (MRP 1-4) are responsible for an accelerated efflux of methotrexate..$^{11}$ Folylpolyglutamyl synthetase (FPGS), which catalyses the polyglutamylation of methotrexate, ${ }^{12}$ causes prolonged intracellular retention of methotrexate and leads to sustained inhibition of dihydrofolate reductase, impeding the transformation of dihydrofolate to tetrahydrofolate (table 1). The roles of MRPs and RFC within the folic acid cycle are well established. ${ }^{13-16}$ Other studies have shown the importance of folate receptors in the uptake of folic acid and methotrexate into activated synovial mononuclear cells. ${ }^{17}$ In contrast to patients with malignancies, it was recently shown that the presence of FPGS in patients with rheumatoid arthritis did not mediate a better response to methotrexate. ${ }^{18}$

In a further attempt to determine influences on the response to methotrexate we investigated whether RFC status and functional MRP (fMRP) in patients with rheumatoid arthritis treated with low dose weekly methotrexate is related to their clinical response to this drug.

\section{METHODS}

\section{Patients}

We enrolled 163 patients in the study ( 116 female, 47 male; mean age 59.5 years). All had rheumatoid arthritis classified according to the American College of Rheumatology (ACR) criteria. ${ }^{19}$ Rheumatoid factor (RF) was present in 102 patients (62.5\%), while 61 were RF negative (37.5\%). Mean (SD) disease duration was 7.6 (7.2) years (range 7 months to 25 years). Ninety six patients were on low dose corticosteroids (59\%) and 139 were on monotherapy with methotrexate; 19 were also receiving chloroquine, three were on sulfasalazine, and two were on ciclosporin. Fifty nine were receiving folic acid supplementation (table 2). In addition, most patients were being treated with non-steroidal anti-inflammatory drugs (NSAIDs), usually diclofenac, ibuprofen, or coxibs; none was on indomethacin.

All patients gave written informed consent and the local ethics committee approved the investigation.

Blood samples for determination of RFC and fMRPs were taken cross sectionally during ongoing methotrexate treatment but at least 12 weeks after its initiation. The mean (SD) weekly dose of methotrexate was 12.2 (3.8) $\mathrm{mg}$ (range 7.5 to $22.5)$ with a treatment duration of 30 (25.1) months (range 4 to 121$)$.

Abbreviations: ACR, American College of Rheumatology; DAS28, 28 joint disease activity score; DMARD, disease modifying antirheumatic drug; EULAR, European League Against Rheumatism; fMRP, functional multidrug resistance proteins; FPGS, folylpolyglutamyl synthetase; MRP, multidrug resistance protein family; NSAID, non-steroidal antiinflammatory drug; RFC, reduced folate carrier; VAS, visual analogue scale 
Table 1 Resistance markers for methotrexate

\begin{tabular}{llll}
\hline Resistance marker & Location & Function & Method of determination \\
\hline $\begin{array}{l}\text { Reduced folate carrier } \\
\text { (RFC) }\end{array}$ & Cell membrane protein & $\begin{array}{l}\text { Influx of reduced folate and } \\
\text { methotrexate }\end{array}$ & RT-PCR \\
$\begin{array}{l}\text { Multidrug resistance } \\
\text { proteins (MRP 1-4) }\end{array}$ & Cell membrane proteins & $\begin{array}{l}\text { Efflux of methotrexate, } \\
\text { cellular detoxification }\end{array}$ & Flow cytometry \\
$\begin{array}{l}\text { Folylpolyglutamyl } \\
\text { synthetase (FPGS) }\end{array}$ & Cytoplasmic enzyme & $\begin{array}{l}\text { Polyglutamylation of } \\
\text { methotrexate and folate } \\
\text { (presumed increase in } \\
\text { efficacy) }\end{array}$ & RT-PCR (not done) \\
\hline RT-PCR, reverse transcriptase polymerase chain reaction. &
\end{tabular}

All clinical and serological variables were evaluated prospectively in the course of routine clinical care, with blinding to the results of RFC and fMRP testing. This evaluation included joint counts, patient and physician global assessment and patient pain assessment by visual analogue scale (VAS), and acute phase reactants. Therapeutic response was evaluated using the EULAR response criteria, which employ the 28 joint disease activity score (DAS28). ${ }^{20-22}$ The DAS was determined prospectively at the initiation of methotrexate treatment and at the time of the present investigation. A DAS28 of more than 5.1 indicates high disease activity; between 3.2 and 5.1, moderate disease activity; and below 3.2, low disease activity. A decrease in DAS28 of $>1.2$ represents a good EULAR response (unless DAS is in the high disease activity range at the end of observation); a decrease of $>0.6$ but $\leqslant 1.2$ is considered a moderate response; a change of $\leqslant 0.6$ (or high disease activity whatever the change in the DAS) is regarded as lack of clinical response. ${ }^{20-22}$ The ACR 20\% (ACR20) response was also evaluated-that is, a $20 \%$ decrease in the number of swollen and painful joints and in at least three of the following: patient pain assessment, patient and physician global assessment, erythrocyte sedimentation rate (ESR) or C reactive protein, and health assessment questionnaire (HAQ) score. $^{23}$

\section{Determination of RFC mRNA expression and MRP function}

The role of the individual resistance factors and their method of determination are shown in table 1. RFC mRNA expression was determined using reverse transcriptase polymerase chain reaction (RT-PCR). Briefly, peripheral blood mononuclear cells were isolated by density gradient centrifugation. Total RNA was isolated using an RNA isolation kit (RNEasy; Qiagen, Valencia, California, USA). cDNA was obtained using Superscript II reverse transcriptase (Life Technologies, Rockville, Maryland, USA). RT-PCR was then carried out. Thirty five PCR cycles were completed (denaturation, annealing, polymerisation), followed by a final elongation step. For RFC, forward primer RFC-617 (5'-CCAAGCGCA GCCTCTTCTTCAACC-3', bases 617-640) and reverse primer RFC-949 (5'-CCAGCAGCGTGGAGGCAGCATCTGCC3', bases 924-949) were used, leading to a product of 333 base pairs (bp). RT-PCR products were separated by $2 \%$ agarose gel electrophoresis with $0.5 \mu \mathrm{g} / \mathrm{ml}$ ethidium bromide for DNA visualisation.

We used $\beta 2$ microglobulin as a housekeeping gene. RFC+ samples were defined by visual detectability of RFC-PCR products after electrophoresis; RFC - samples yielded no visible bands of PCR products (low RFC mRNA copy number). As there was a large variation in expression of RFC (from not visible to very intense bands) and as two distinct patterns were found (negative or positive), further densitometric analyses of the bands was not undertaken. Human erythroleukaemia K562 cells were included as a positive control in all assays. ${ }^{24} 25$

MRP function was measured by flow cytometry of total mononuclear blood cells using a calcein acetoxymethylester/ probenecid assay with a final probenecid concentration of $1 \mathrm{mM}^{26-31}$ In brief, cells were preincubated with warm RPMI 1640 medium after several washing steps to remove any remaining serum components, followed by a 15 minute incubation with calcein acetoxymethylester. After 90 minutes' incubation in medium with or without probenecid as modulator of MRP activity, fluorescence was measured with a FACScan cytometer (Becton Dickinson, Franklin Lakes, New Jersey, USA). fMRP was defined as the transport of methotrexate and its successful blocking by probenecid: fMRP+ means transport of methotrexate through the cell membrane, inhibitable by probenecid; fMRP- means no efflux because of the absence of any transport mechanism, or transport of methotrexate by another mechanism not inhibitable by probenecid, such as P-glycoprotein (in both cases there is no functional MRP present).

The mean fluorescence index for fMRP+ was 1.12 (95\% confidence interval (CI), 1.07 to 1.32 ), and for fMRP- 0.93 (0.9 to 0.97 ). The cut off level for MRP functionality was defined as $>1.00$.

Table 2 Mean dose of methotrexate and other disease modifying antirheumatic drugs

\begin{tabular}{|c|c|c|c|c|c|}
\hline & \multirow[b]{2}{*}{ Methotrexate dose* } & \multirow[b]{2}{*}{ Folic acid suppl } & \multicolumn{3}{|c|}{ Dual therapy with } \\
\hline & & & Chloroquine & Sulfasalazine & Ciclosporin \\
\hline $\begin{array}{l}\text { fMRP-/RFC+ } \\
(\mathrm{n}=70)\end{array}$ & $12.1(3.9) \mathrm{mg}$ & $29(41 \%)$ & $11(15.7 \%)$ & $1(1.4 \%)$ & $1(1.4 \%)$ \\
\hline $\begin{array}{l}\text { fMRP-/RFC- } \\
(n=32)\end{array}$ & $12.1(3.7) \mathrm{mg}$ & $9(28 \%)$ & $3(9.3 \%)$ & $1(3.1 \%)$ & $1(3.1 \%)$ \\
\hline $\begin{array}{l}\text { fMRP }+/ R F C+ \\
(n=33)\end{array}$ & $12.7(3.7) \mathrm{mg}$ & $12(36 \%)$ & $1(3.0 \%)$ & $1(3.0 \%)$ & 0 \\
\hline $\begin{array}{l}\text { fMRP }+/ \text { RFC- } \\
(n=28)\end{array}$ & $12.0(3.9) \mathrm{mg}$ & $9(32 \%)$ & $4(14.2 \%)$ & 0 & 0 \\
\hline
\end{tabular}

Values are $\mathrm{n}(\%)$ or *mean (SD).

FMRP, functional multidrug resistance proteins; RFC, reduced folate carrier; suppl, supplementation; +, positive; - , negative. 


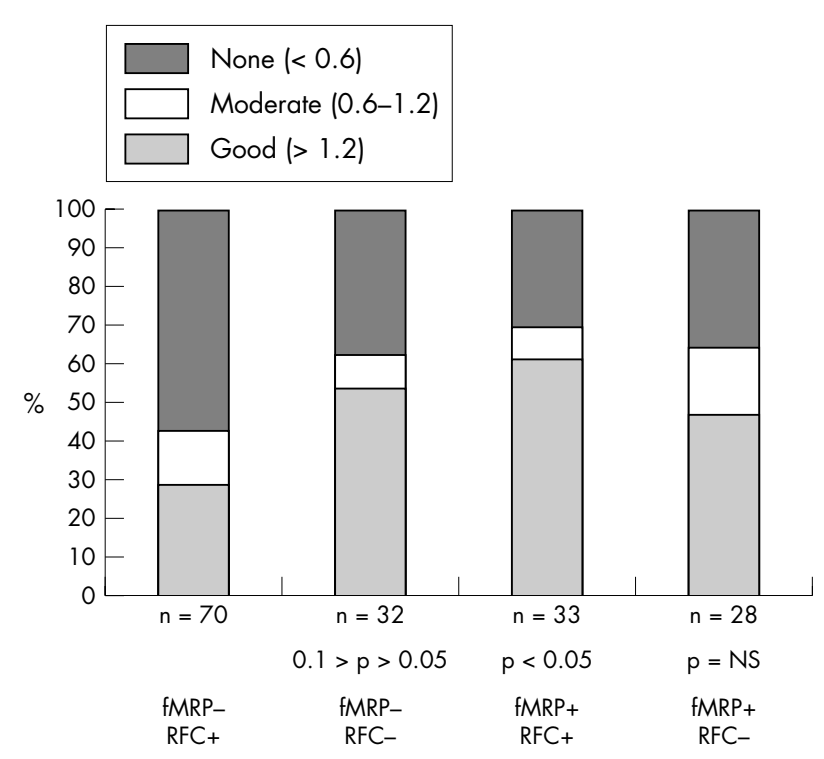

Figure 1 Good, moderate, and low DAS28 response in each of the four groups. Probability ( $p$ ) values relate to good responses in each group compared with FMRP - /RFC+ patients. Mean change in DAS was significantly lower among FMRP - /RFC+ patients than among either FMRP - /RFC - or FMRP+/RFC+ patients. DAS28, 28 joint disease activity score; fMRP, functional multidrug resistance proteins; RFC, reduced folate carrier.

Probenecid may not be equally effective on all subgroups of MRP, but at the time of testing it was the best specific modulator available; therefore fMRP refers to a group of multidrug resistance proteins including all known MRP subgroups, in contrast to P-glycoprotein.

\section{Analyses}

In analogy with their role in malignant diseases, ${ }^{913}$ the presence of RFC and the absence of fMRP was hypothesised to be associated with a better therapeutic response to methotrexate and thus to have prognostic value. Patients were therefore divided into four groups according to the presence or absence of RFC and fMRP. The frequency of EULAR and ACR20 responders was determined for each group. In addition, mean (SD) change in DAS was determined for each group and the results were compared with those of the MRP-/RFC+ group assumed to obtain the greatest clinical benefit.

Statistical evaluation was carried out using Student's $t$ test, comparing the mean change of DAS28 in each group with the fMRP-/RFC+ group. The frequencies of good, good +

Table 3 Mean 28 joint disease activity score (DAS28) and reduction in DAS28

\begin{tabular}{|c|c|c|c|c|}
\hline $\begin{array}{l}\text { Groups } \\
\text { according to } \\
\text { resistance } \\
\text { markers }\end{array}$ & $\begin{array}{l}\text { Change in } \\
\text { DAS28 }\end{array}$ & $\begin{array}{l}\text { Mean DAS28 } \\
\text { at start of } \\
\text { treatment }\end{array}$ & $\begin{array}{l}\text { Mean DAS28 } \\
\text { at time of } \\
\text { blood } \\
\text { sampling }\end{array}$ & $\begin{array}{l}\text { p Value } v \\
\text { fMRP-/ } \\
\text { RFC+ }\end{array}$ \\
\hline \multirow{4}{*}{$\begin{array}{l}\text { fMRP }-/ \text { RFC+ } \\
(n=70) \\
\text { fMRP }-/ R F C- \\
(n=32) \\
\text { fMRP }+/ R F C+ \\
(n=33) \\
\text { fMRP }+/ R F C- \\
(n=28)\end{array}$} & $0.71(1.27)$ & $3.08(1.02)$ & \multicolumn{2}{|l|}{$2.37(1.00)$} \\
\hline & $1.23(1.44)$ & $3.22(1.30)$ & $1.99(0.93)$ & 0.035 \\
\hline & $1.32(1.36)$ & $3.38(1.10)$ & $2.05(1.14)$ & 0.014 \\
\hline & $1.09(1.29)$ & $3.39(0.95)$ & $2.30(0.98)$ & NS \\
\hline \multicolumn{5}{|c|}{$\begin{array}{l}\text { Values are mean (SD). } \\
\text { fMRP, functional multidrug resistance proteins; RFC, reduced folate } \\
\text { carrier. }\end{array}$} \\
\hline
\end{tabular}

moderate, and ACR20 responders were compared by $\chi^{2}$ testing.

\section{RESULTS}

Seventy of the 163 patients fell into the fMRP-/RFC+ group $(43.0 \%)$. The therapeutic characteristics of this group did not differ statistically from those of the other groups (table 2). In contrast to our expectations, this group had the lowest mean DAS improvement (mean reduction of 0.71 ; table 3 ). In fact, only $29 \%$ of these patients had a good DAS28 response (fig 1), and only $36 \%$ fulfilled the ACR20 criteria. Interestingly, both the fMRP-/RFC - and the fMRP+/RFC+ groups had significantly greater mean improvements in DAS than the fMRP-/RFC+ group ( 1.23 and 1.32 , respectively; $p=0.035$ and $p=0.014$ ) (table 3 ). Moreover, in these two groups good EULAR responses were seen in $53 \%$ and $60 \%$ of the patients, respectively, and $57 \%$ and $55 \%$ achieved an ACR20 response $(0.1>p>0.05$ and $p<0.05$, respectively, compared with fMRP-/RFC+ patients). In the fMRP+/RFC - group intermediate results were obtained: $46 \%$ had a good DAS28 response, while $43 \%$ achieved ACR20. Thus concordance for either the presence or the absence of fMRPs and RFC conferred a high likelihood of a good response to methotrexate. In contrast, the fMRP-/RFC+ group was associated with highest risk of lack of response (fig 1 ).

The mean methotrexate doses were similar among the different groups (table 2). Thus differences in response to treatment were not the result of different doses of methotrexate.

\section{DISCUSSION}

For many years and in many clinical and therapeutic settings, attempts have been made to predict responsiveness to DMARD therapy in rheumatoid arthritis. However, these attempts have not been successful hitherto. In the present study we show that patients who are concordant for either the presence of or the lack of fMRPs and RFC have better responses to methotrexate than those who are not concordant for these proteins. In contrast to our expectations, a particularly low clinical response rate was found among patients with fMRP-/RFC+ status.

The data obtained suggest a predictability of response to methotrexate. In addition, they may allow some insight into mechanisms of methotrexate unresponsiveness. First, functional MRP may not be the cause of resistance to methotrexate in rheumatoid arthritis, as very good clinical responses were obtained in MRP+ patients. Nevertheless, we cannot exclude the possibility that MRP family members (for example, MRP4) other than those investigated here (MRP 13) may be involved in methotrexate resistance in rheumatoid arthritis. $^{32}{ }^{33}$ Also, some patients may have increased FPGS activity, preventing methotrexate polyglutamates from being effluxed by MRPs and allowing methotrexate responsiveness regardless of the presence of MRP. However, we did not find the methotrexate response to be associated with presence of absence of FPGS. ${ }^{18}$ Second, as the presence of RFC and the absence of MRP confer the highest intracellular methotrexate concentrations, ${ }^{73435}$ the weak clinical response to methotrexate in this group of patients suggests that the methotrexate effects in rheumatoid arthritis and folate mediated methotrexate effects are based on different intracellular pathways. This is further supported by the lack of association of clinical response with the presence or absence of FPGS. ${ }^{18}$ Thus it may be important in future studies to have a combined look at the mechanisms studied here, as well as studying the inhibition of AICAR transformylase which plays an essential role in the mechanism of action of methotrexate in rheumatoid arthritis. ${ }^{7}$ 
The observation that methotrexate had only weak efficacy in $\mathrm{fMRP}-/ \mathrm{RFC}+$ patients may not necessarily indicate that the influx of methotrexate into the cell (as mediated by RFC) is insufficient to allow methotrexate to exert its effect as a DMARD within the cell. Other pathways for ingress of methotrexate into the cell which were not examined in this study might be more efficient in this respect. ${ }^{17}$ In addition, the influence of MRP on methotrexate may be more complex than simply transporting the drug out of the cell. Moreover, given the result in this subset of $\mathrm{MRP}-/ \mathrm{RFC}+$ patients, it is unlikely that methotrexate upregulates MRPs, as has been described for other agents such as cisplatinum compounds or the glucocorticoid dexamethasone. ${ }^{36}{ }^{37}$ Ma et al have reported that in folate depleted breast cancer cells, exposure to low dose methotrexate under certain conditions results in a decrease in RFC-1 expression, and the initial rate of methotrexate uptake over time decreased to $22 \%$ of the baseline value. ${ }^{38}$ As the current investigation was carried out 12 weeks after the initiation of methotrexate, such effects, if present in vivo, could also be responsible for some of our observations.

Among rheumatoid patients treated with methotrexate, $30-50 \%$ do not fulfil response criteria. These data, obtained in clinical trials, are confirmed here in a cohort of patients followed during routine clinical care. However, the highest frequency of non-responders (57\%) was observed among the fMRP - /RFC+ patient population, while the lowest frequency of DAS28 non-responders (37\%) was seen among fMRP-/ RFC - patients.

The results we obtained also suggest an impact on clinical decision making because they could provide rheumatologists with a tool to predict responsiveness to methotrexate therapy. As $57 \%$ of the $\mathrm{fMRP}+/ \mathrm{RFC}+$ and $\mathrm{fMRP}-/ \mathrm{RFC}-$ patients had a good clinical response, compared with only half that proportion in $\mathrm{fMRP}-/ \mathrm{RFC}+$ patients, determination of these proteins may be helpful in predicting the probability of responsiveness to methotrexate.

At present, neither responsiveness to traditional DMARDs nor responsiveness to biological agents can be predicted on clinical or laboratory grounds. We have revealed a potential tool for discrimination of likely methotrexate responders from likely non-responders. Further studies in other patient populations will be needed to confirm these results. However, once confirmed, this finding could be a major breakthrough in predicting responsiveness to treatment in rheumatoid arthritis.

\section{ACKNOWLEDGEMENTS}

This study was supported by the "Jubiläumsfonds der Oesterreichischen Nationalbank" (project number 8783).

\section{Authors' affiliations}

J Wolf, B Leeb, J S Smolen, Second Department of Medicine, Lainz

Hospital, Vienna, Austria

T Stranzl, M Filipits, G Pohl, R Pirker, Department of Internal Medicine I, University of Vienna

\section{REFERENCES}

1 Siegmeth W, Eberl R, Tausch G, Raith W. Comparative study of the effect of the antimetabolic agent methotrexate in psoriasis, psoriatic arthropathy and rheumatoid arthritis. Verh Dtsch Ges Rheumatol 1969;1:383-7 [In German.].

2 Hoffmeister RT. Methotrexate therapy in rheumatoid arthritis: 15 years experience. Am J Med 1983;75:69-73.

3 Weinblatt ME, Coblyn JS, Fox DA, Fraser PA, Holdsworth DE, Glass DN, et al. Efficacy of low-dose methotrexate in rheumatoid arthritis. N Engl J Med 1985;312:818-22.

4 Korn S, Dehoratius RJ. Methotrexate in the treatment of rheumatoid arthritis. Am Fam Physician 1989;40:243-6.

5 Leeb BF, Smolen JS. Low dose methotrexate therapy in chronic polyarthritis an update. Acta Med Austriaca 1996;23:114-19.
6 Kremer JM. Methotrexate and emerging therapies. Rheum Dis Clin North Am 1998;24:651-8.

7 Chan ES, Cronstein BN. Molecular action of methotrexate in inflammatory diseases. Arthritis Res 2002:4:266-73.

8 van Ede AE, Laan RF, Rood MJ, Huizinga TW, van de Laar MA, van Denderen $\mathrm{CJ}$, et al. Effect of folic or folinic acid supplementation on the toxicity and efficacy of methotrexate in rheumatoid arthritis: a forty-eight week, multicenter, randomized double-blind, placebo-controlled study. Arthritis Rheum 2001;44:1515-24.

9 Gorlick R, Goker E, Tripett T, Steinherz P, Elisseyeff Y, Mazumdar M, et al. Defective transport is a common mechanism of acquired methotrexate resistance in acute lymphocytic leukemia and is associated with decreased reduced folate carrier expression. Blood 1997:89:1013-18.

10 Borst P, Evers R, Kool M, Wijnholds J. A family of drug transporters : the multidrug resistance-associated proteins. J Natl Cancer Inst 2000:92:1295-302.

11 Hooijberg JH, Broxterman HJ, Kool M, Assaraf YG, Peters GJ, Noordhuis P, et al. Antifolate resistance mediated by the multidrug resistance proteins MRP and MRP2. Cancer Res 1999;59:2532-5.

12 Longo GS, Gorlick R, Tong WP, Lin S, Steinherz P, Bertino JR. $\gamma$-glutamyl hydrolase and folylpolyglutamate synthetase activities predict polyglutamylation of methotrexate in acute leukaemia. Oncol Res polyglutamylation

13 Sirotnak FM. Obligate genetic expression in tumor cells of a fetal membrane property mediating "folate" transport: biological significance and implications for improved therapy of human cancer. Cancer Res 1985;45:3992-4000

14 Henderson GB. Folate-binding proteins. Annu Rev Nutr 1990;10:319-35.

15 Zeug H, Chen ZS, Belinsky MG, Rea PA, Uruh GD. Transport of methotrexate (MTX) and folates by multidrug resistance protein (MRP) 3 and MRP 1: effect of polyglutamylation on MTX transport. Cancer Res $2001 ; 61: 7225-32$.

16 Ito K, Oleschuk CJ, Westlake C, Vasa MZ, Deeley RG, Cole SP. Mutation of Trp 1254 in the multispecific organic anion transporter multidrug resistance protein 2 (MRP 2) (ABC C2) alters substrate specificity and results in loss of methotrexate transport activity. J Biol Chem 2001;276:38108-14.

17 Nakashima-Matsushita N, Homma T, Yu S, Matsuda T, Sunahara N, Nakamura $T$, et al. Selective expression of folate receptor $\beta$ and its possible role in methotrexate transport in synovial macrophages from patients with rheumatoid arthritis. Arthritis Rheum 1999;42:1609-16.

18 Stranzl T, Wolf J, Leeb BF, Smolen JS, Pirker R, Filipits M. Expression of folylpolyglutamyl synthetase predicts poor response to methotrexate therapy in patients with rheumatoid arthritis. Clin Exp Rheumatol 2003;21:27-32.

19 Arnett FC, Edworthy SM, Bloch DA, McShane DJ, Fries JF, Cooper NS, et al. The American Rheumatism Association 1987 revised criteria for the classification of rheumatoid arthritis. Arthritis Rheum 1988;31:315-24.

20 Prevoo ML, van't Hof MA, Kuper HH, van Leeuwen MA, van de Putte LB, van Riel PL. Modified disease activity scores that include twenty-eight-joint counts. Arthritis Rheum 1995;38:44-8

21 van Gestel AM, Prevoo MLL, van't Hof MA, van Rijswijk MH, van de Putte LB, van Riel PL. Development and validation of the European League Against Rheumatism response criteria for rheumatoid arthritis: comparison with the preliminary American College of Rheumatology and the World health Organisation/International League Against Rheumatism Criteria. Arthritis Rheum 1996:39:34-40.

22 van Gestel AM, Anderson JJ, van Riel PL, Boers M, Haagsma CJ, Rich B, et al. $A C R$ and EULAR improvement criteria have comparable validity in rheumatoid arthritis trials. J Rheumatol 1999;26:705-11.

23 Felson DT, Anderson JJ, Boers M, Bombardier C, Furst D, Goldsmith C, et al. American College of Rheumatology. Preliminary definition of improvement in rheumatoid arthritis. Arthritis Rheum 1995;38:727-35.

24 Zhang L, Taub JW, Williamson M, Wong SC, Hukku B, Pullen J, et al. Reduced folate carrier gene expression in childhood acute lymphoblastic leukaemia: relationship to immunophenotype and ploidy. Clin Cancer Res 1998;4:2169-77.

25 Wong SC, Zhang L, Proefke SA, Hukku B, Matherly LH. Gene amplification and increased expression of the reduced folate carrier in transport elevated K562 cells. Biochem Pharmacol, 1998 1, 55:1135-8.

26 van Aubel RA, Smeets PH, Peters JG, Bindels RJ, Russel FG. The MRP4/ $A B C C 4$ gene encodes a novel apical organic anion transporter in human kidney proximal tubules: putative efflux pump for urinary cAMP and cGMP. J Am Soc Nephrol 2002;13:595-603.

27 Assaraf YG, Rothem L, Hooijberg JH, Stark M, Ifergan I, Kathmann I, et al. Loss of multidrug resistance protein 1 expression and folate efflux activity results in a highly concentrative folate transport in human leukemia cells. J Biol Chem 2003;278:6680-6.

28 Hong J, Lambert JD, Lee SH, Sinko PJ, Yang CS. Involvement of multidrug resistance-associated proteins in regulating cellular levels of $(-)$ epigallocatechin-3-gallate and its methyl metabolites. Biochem Biophys Res Commun, 2003 10, 310:222-7.

29 Zamek-Gliszczynski MJ, Xiong H, Patel NJ, Turncliff RZ, Pollack GM, Brouwer KL. Pharmacokinetics of 5 (and 6)-carboxy-2', $7^{\prime}$-dichlorofluorescein and its diacetate promoiety in the liver. J Pharmacol Exp Ther 2003;304:801-9.

30 Decleves X, Fajac A, Lehmann-Che J, Tardy M, Mercier C, Hurbain I, et al. Molecular and functional MDR1-Pgp and MRPs expression in human glioblastoma multiforme cell lines. Int J Cancer, 2002 10, 98:173-80.

31 Laupeze B, Amiot L, Payen L, Drenou B, Grosset JM, Lehne G, et al. Multidrug resistance protein (MRP) activity in normal mature leucocytes and 
CD34-positive hematopoietic cells from peripheral blood. Life Sci 2001;68:1323-31.

32 Yudoh K, Matsuno H, Nakazawa F, Yonezawa T, Kimura T. Increased expression of multidrug resistance of P-glycoprotein on Th 1 cells correlates with drug resistance in rheumatoid arthritis. Arthritis Rheum

1999:42:2014-15.

33 Rahman P, Hefferton D, Robb D. Increased MDR 1 P-glycoprotein expression in methotrexate resistance: comment on the article by Yudoh et al. Arthritis Rheum 2000:43:1661-2.

34 Henderson GB, Huennekens FM. Membrane-associated folate transport proteins. Methods Enzymol 1986;122:260-9.
35 Gong M, Yess J, Connolly T, Ivy SP, Ohnuma T, Cowan KH, et al. Molecular mechanism of antifolate transport-deficiency in a methotrexate-resistant MOLT-3 human leukemia cell line. Blood 1997;89:2494-9

36 Schrenk D, Baus PR, Ermel N, Klein C, Vorderstemann B, Kauffmann HM. Upregulation of transporters of the MRP family by drugs and toxins. Toxicol Lett $2001 ; 120: 51-7$.

37 Salmon SE, Dalton WS. Relevance of multidrug resistance to RA, development of a new therapeutic hypothesis. J Rheumatol Suppl 1996;44:97-101.

$38 \mathrm{Ma} \mathrm{D}$, Huang $\mathrm{H}$, Moscow JA. Down-regulation of reduced folate carrier gene (RFC1) expression after exposure to methotrexate in ZR-75-1 breast cancer cells. Biochem Biophys Res Commun 2000;279:891-7.

\section{Register now!}

10th European Forum on Quality Improvement in Health Care 13-15 April 2005, ExCel Conference Centre, London For further information on how to register please go to: http://www.quality.bmipg.com 